\title{
PENGARUH WAKTU FERMENTASI DAN KOMPOSISI LIMBAH ECENG GONDOK (Eichhornia crassipes) UNTUK MENGHASILKAN GAS BIO DENGAN METODE HIDROLISA BASA MENGGUNAKAN NATRIUM HIDROKSIDA (NaOH)
}

\section{EFFECT OF FERMENTATION TIME AND WATER HYACINTH (Eichhornia Crassipes) WASTE COMPOSITION TO PRODUCE BIOGAS BY ALKALI HYDROLYSIS METHOD USING SODIUM HYDROXIDE} $(\mathrm{NaOH})$

\author{
Setiaty Pandia, Pri Hartini* \\ Departemen Teknik Kimia, Fakultas Teknik, Universitas Sumatera Utara, \\ Jl. Almamater Kampus USU, Medan 20155, Indonesia \\ "Email : pri_hartini12@yahoo.com
}

\begin{abstract}
Abstrak
Eceng gondok (Eichhornia crassipes) merupakan tanaman yang menjadi limbah perairan dan keberadaannya belum banyak dimanfaatkan. Kandungan selulosa, hemiselulosa, dan lignin di dalamnya dapat dimanfaatkan menjadi gas bio melalui proses fermentasi.Penelitian ini bertujuan untuk mengetahui efek metode pre-treatment alkali terhadap volume gas bio dan persentase penyisihan Total Suspended Solid(TSS).Penelitian ini dilakukan pada eceng gondok yang difermentasi pada konsentrasi $\mathrm{NaOH} 2,86 \mathrm{M} ; 3 \mathrm{M} ; 4 \mathrm{M}$; dan 6,67 M, dicampur dengan air pada rasio eceng gondo:air 70:30 (v/v); 50:50 (v/v); 30:70 (v/v) dan 100:0 (v/v) dan starter kotoran sapi di dalam digester anaerobik sistembatch kapasitas 2,5 L. Pada penelitian ini produksi gas bio tertinggi terjadi pada konsentrasi $\mathrm{NaOH}$ 6,67 $\mathrm{M}$ dengan rasio perbandingan eceng gondok:air70:30 (v/v) dihasilkan volume gas bio $506 \mathrm{~mL}$ dan persentase penyisihan TSS sebesar $93,23 \%$. Hasil minimum terjadi pada konsentrasi $\mathrm{NaOH}$ $3 \mathrm{M}$ dengan rasio perbandingan eceng gondok:air 30:70 (v/v) dihasilkan volume gas bio $158 \mathrm{~mL}$ dan persentase penyisihan TSS sebesar $81,48 \%$.
\end{abstract}

Kata kunci: eceng gondok, perlakuan awal, digester anaerobik, $\mathrm{NaOH}$, gas bio, TSS

\begin{abstract}
Water hyacinth (Eichhornia crassipes) is a plant that become aquatic waste and its existence has not yet widelyused. The content of cellulose, hemicellulose, and lignin inside it can be used into biogas through fermentation process.The purpose of this research was to determine the effect of alkali pretreatment methods on the yield biogas volume and Total Suspended Solid (TSS) revomal percentage. The study was did by fermentation process the water hyacinth with $\mathrm{NaOH}$ concentration of 2,$86 ; 3 ; 4$; and $6,67(\mathrm{M})$ with water in ratio hyacinth:water 70:30; 50:50; 30:70 and 100:0 (v/v) mixed with cow dug starter in an anaerobic digester batch system of $2,5 \mathrm{~L}$ capacity. In this study the highest biogas production at $\mathrm{NaOH}$ concentration $6,67 \mathrm{M}$ was in ratio of 70:30 (v/v) with yield biogas volume $506 \mathrm{~mL}$ and TSS revomal percentage of 93,23\%. Minimum value of gasbio production concentration of $\mathrm{NaOH} 3 \mathrm{M}$ withwater hyacinth:water ratio 30:70 (v/v) generate yield biogas volume $158 \mathrm{~mL}$ and TSS revomal percentage of $81,48 \%$.
\end{abstract}

Key word: water hyacinth, pre-treatment, anaerobic digester, $\mathrm{NaOH}$, gasbio, TSS

\section{Pendahuluan}

Sumber energi fosil sebagai bahan bakar minyak memang sangat terbatas, dikarenakan semakin meningkatnya kebutuhan akan penggunaan energi dengan pertambahan jumlah penduduk dan peningkatan konsumsi oleh masyarakat [2]. Hal ini diperkirakan akan terus meningkat pada tahun berikutnya, sehingga mengakibatkan persediaan minyak bumi yang ada di indonesia semakin menipis [3].

Eceng gondok (Eichhornia crassipes) sangat baik digunakan dalam pembuatan gas bio dengan beberapa perlakuan awal untuk meningkatkan hasil gas bio.Namun, permasalahan timbul karena biomassa mengandung selulosa dan lignin yang sulit didegradasi akan menyebabkan permasalahan pada proses.Untuk itu hal yang 
perlu dilakukan dengan perlakuan khusus untuk mendegradasi lignin [5]. Adapun bahan penyanggayang digunakan adalah natrium karbonat $\left(\mathrm{Na}_{2} \mathrm{CO}_{3}\right)$. Pre-treatment alkalinitas dengan Natrium Hidroksida $(\mathrm{NaOH})$ bertujuan untuk memutuskan lignin pada eceng gondok dan mempercepat proses hidrolisis sehingga proses pembentukan gas metana lebih cepat, sedangkan penambahan natrium karbonat $\left(\mathrm{Na}_{2} \mathrm{CO}_{3}\right)$ bertujuan untuk mentralkan $\mathrm{pH}$ pada slurry eceng gondok dengan proses anaerobik terhadap gas bio yang dihasilkan dan mempercepat proses pembentukan metana $\left(\mathrm{CH}_{4}\right)$ $[9,13]$.

Dalam penelitian ini maka dipilih pre-treatment kombinasi fisik dan kimia dengan memotong ukuran biomassa lebih kecil dan penambahan bahan kimia untuk melepaskan lignin [4].

\section{Teori}

Eceng gondok adalah species Eichhornia crassipes Solms, biomassa air yang produksi dan pertumbuhannya sangat pesat di berbagai daerah [4]. Pertumbuhan eceng gondok dapat mencapai $1,9 \%$ per hari dengan tinggi antara $0,3-0,5 \mathrm{~m}$ [14]. Eceng gondok biasanya tumbuh di kolamkolam dangkal, tanah basah dan rawa, aliran air yang lambat seperti danau, tempat penampungan air dan sungai [24]. Menggunakan eceng gondok sebagai substrat untuk produksi gas bio merupakan strategi pengendalian yang menguntungkan karena dapat meningkatkan invasi tanaman dan produksi gas bio yang produktif [18].

Teknologi pre-treatment/praperlakuan yang dilakukan pada dasarnya adalah untuk mengubah atau memindahkan komposisi dan struktur yang menghalangi proses hidrolisis yang bertujuan untuk meningkatkan laju aktivitas enzimatis dan hasil fermentasi yang menghasilkan glukosa dari selulosa atau hemiselulosa [13].

Gas bio merupakan salah satu sumber energi terbarukan yang dapat menjawab kebutuhan dan energi alternatif ramah lingkungan yang dapat digunakan sebagai sumber energi penggerak generator listrik dan dibakar seperti gas elpiji (LPG) [10]. Gas bio dapat diproduksi melalui digesti anaerobik dengan bahan kotoran dan limbah. Gas bio yang dihasilkan dapat digunakan sebagai bahan bakar untuk berbagai tujuan seperti memasak serta bisa dikonversi menjadi energi listrik [15]. Prinsip dasar teknologi gas bio adalah proses penguraian bahan-bahan organik olehmikroorganisme dalam kondisi tanpa udara (anaerob) untuk menghasilkan campuran daribeberapa gas, di antaranya metana dan $\mathrm{CO}_{2}$ [19].

Digesti anaerobik dapat dilakukan dengan satu tahap dan dua tahap. Pada proses satu tahap ada empat proses yaitu, hidrolisis, asidogenesis, asetogenesis dan metanogenesis dilakukan pada reaktor yang sama [8]. Konversi bahan organik menjadi gas metana dapat dibagi menjadi empat tahap utama yaitu hidrolisis,asidogenesis, asetogenesis dan metanogenesis [2]. Komponen terbesar yang terkandung dalam gas bio adalah $55-70 \%$, karbon dioksida27 - $45 \%$ serta sejumlah kecil, nitrogen dan hidrogen sulfida [20].

\section{Metodologi Penelitian \\ Bahan dan Peralatan}

Bahan baku yang digunakan pada penelitian adalah eceng gondok dan air. Bahan pembantu yang digunakan glukosa dan mikroorganisme yang berasal dari kotoran sapi yang di campur dengan air dengan perbandingan 1:1 yaitu $25 \%$ dari volume digester terisi $(2 \mathrm{~L})$. Alat utama yang digunakan adalah digester anaerobik.

\section{Prosedur Percobaan}

Sampel (eceng gondok) dipotong $2 \mathrm{~cm}$ dan dikeringkan, ditreatment dengan $\mathrm{NaOH}$ dan $\mathrm{H}_{2} \mathrm{SO}_{4}$ dicampur air dalam rasio 70:30; 50:50; 30:70 dan 100:0 (w/w), kemudian ditambahkan starter (kotoran sapi) yang telah diaklimatisasi serta glukosa. Bahan isian dimasukkan ke dalam digester sebanyak $80 \%$ dari volume digester $(2,5$ L) yaitu sebanyak 2L.Selanjutnya difermentasikan hingga tercapai keadaan tunak. Tangki digester dihubungkan ke alat pengukur volume gas bio, dimana volume gas diukur setiap tiga hari.

Pada tahap ini percobaan dilakukan pada digester anaerobik sistem batch. Dengan $\mathrm{pH}$ dijaga konstan antara 6,2-8, dan pada temperatur lingkungan $\left(25-30{ }^{\circ} \mathrm{C}\right)$. Diamati paramaterparameter percobaan yaitu $\mathrm{pH}$, Chemical Oxygen Demand (COD), Total Suspended Solid (TSS), dan volume gas bio hingga tercapai keadaan tunak, kemudian dilakukan uji nyala. Periode pengamatan dilakukan setiap 3 hari.

\section{Hasil Penelitian \\ Karakteristik Limbah Eceng Gondok}

Nilai COD dan TSS yang besar menunjukan adanya tingginya kandungan zat organik di dalam limbah eceng gondok. Hal ini menunjukkan bahwa limbah ini bersifat mudah terbiodegradasi untuk dijadikan sebagai salah satu bahan baku pembuatan gas bio [6]. Adapun karakteristik dari limbah eceng gondok sebelum fermentasi dapat dilihat pada Tabel 1. 
Tabel 1. Karakteristik dari Limbah Eceng Gondok sebelum Fermentasi

\begin{tabular}{|c|c|c|c|c|}
\hline $\begin{array}{c}\text { Eceng } \\
\text { gondok:air }\end{array}$ & $\begin{array}{c}\text { Konsentrasi } \\
\text { NaOH (M) }\end{array}$ & $\mathbf{p H}$ & $\begin{array}{c}\text { TSS } \\
(\mathbf{m g} / \mathbf{L})\end{array}$ & $\begin{array}{c}\text { COD } \\
(\mathbf{m g} / \mathbf{L})\end{array}$ \\
\hline $70: 30$ & 6,67 & 7 & 3017 & 19400 \\
\hline $50: 50$ & 2,86 & 7 & 2850 & 18500 \\
\hline $30: 70$ & 3,00 & 6,8 & 2585 & 15870 \\
\hline $100: 0$ & 4,00 & 7,8 & 3400 & 19950 \\
\hline
\end{tabular}

\section{Pembahasan}

\section{Pengaruh Waktu Fermentasi terhadap}

\section{Volume Gas Bio}

Dalam penelitian ini dapat dilihat produksi gas bio yang optimum dari berbagai variasi rasio berat limbah padat. Hal ini dilakukan untuk mengetahui seberapa besar pengaruh proses pretreatment pada eceng gondok terhadap jumlah gas bio yang dihasilkan. Oleh karena itu, dari Gambar 1 dapat dilihat produksi gas bio pada beberapa komposisi.

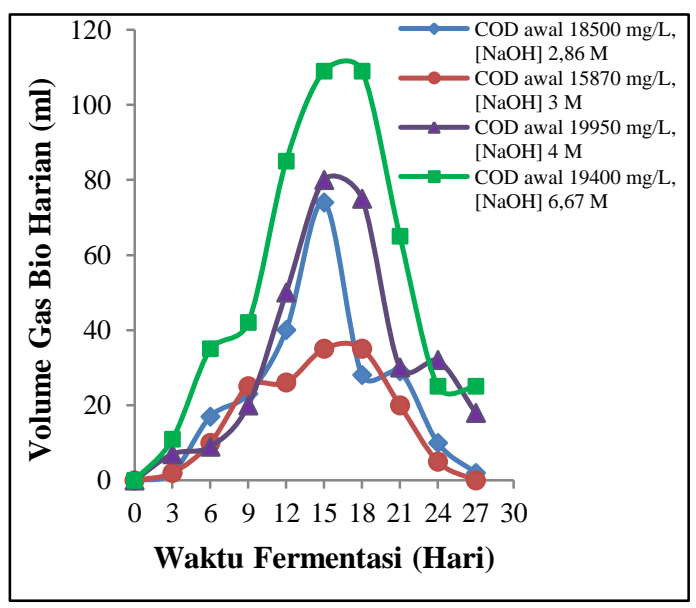

Gambar 1. Pengaruh Waktu Fermentasiterhadap Volume Gas Bio

Pada Gambar 1 dapat dilihat bahwa pada hari ke-15 menunjukkan volume gas bio yang dihasilkan mengalami peningkatan yang maksimal dari masing-masing komposisi. Hal tersebut karena proses fermentasi anaerob sudah mencapai tahap akhir yaitu tahap metanogenesis untuk menghasilkan gas metana. Apabila bakteri metanogenik telah maksimum, maka bakteri tersebut akan menggunakan hasil dari tahap asidifikasi yaitu asam asetat, karbondioksida, dan hidrogen untuk menghasilkan gas metana[7].

Pada penelitian ini gas bio minimum diperoleh pada konsentrasi NaOH 3 M. Gas bio mulai dihasilkan pada hari ke-3, kemudian pada hari ke -15 menghasilkan gas bio yang maksimum sebesar $80 \mathrm{~mL}$. Sedangkan perolehan gas bio maksimum diperoleh pada konsentrasi
$\mathrm{NaOH}$ 6,67 M, gas bio mulai dihasilkan pada hari ke-3 proses fermentasi kemudian mengalami kenaikan hingga menghasilkan gas bio yang maksimum pada hari ke-15 sebesar $109 \mathrm{ml}$.

Keberhasilan proses metanogenesis dapat diketahui dari tereduksinya COD terlarut [23]. Semakin besar reduksi COD, berarti bahan organik yang terdegradasi menjadi asam-asam organik juga semakin besar. Asam-asam organik inilah yang kemudian terkonversi menjadi gas metan [1]. Dapat dilihat pada grafik COD tertinggi yaitu $19950 \mathrm{mg} / \mathrm{L}$ menghasilkan gas bio tertinggi. Sedangkan untuk COD terendah yaitu $15870 \mathrm{mg} / \mathrm{L}$ menghasilkan gas bio terendah.

Berdasarkan penelitian terdahulu, eceng gondok dengan proses pre-treatment dengan variabel berubah konsentrasi $\mathrm{NaOH}$ blanko, $1 \%$ $(\mathrm{wt} / \mathrm{wt})$ dan $3 \%(\mathrm{wt} / \mathrm{wt})$, hasil penelitian pada pre-treatment $\mathrm{NaOH} 3 \%$ menghasilkan volume gas bio dan kadar gas metana paling tinggi daripada $\mathrm{NaOH} 1 \%$ dan blanko. Untuk $\mathrm{NaOH}$ $3 \%$ volume gas bio yang dihasilkan 20,572 liter gasbio/kg eceng gondok dan kadar metana sebesar 78,47 \%. Hal ini dapat terjadi karena $\mathrm{NaOH} 3 \%$ secara signifikan mendegradasi lignin dan mampu melarutkan hemiselulosa sehingga mikroba lebih mudah menghidrolisa selulosa menjadi glukosa dan xylosa yang merupakan sumber karbon organik untuk pertumbuhan mikroba [16]. Dari hasil penelitian ini, diperoleh total gas bio pada COD awal 19400, konsentrasi $\mathrm{NaOH}$ 6,67 M dari hari ke-0 hingga hari ke-27 sebesar $506 \mathrm{ml}$.

Pada Gambar 1dapat dilihat bahwa produksi gas bio maksimum pada hari ke-15. Hal ini menunjukkan bahwa bakteri metanogenik bekerja secara maksimum pada hari ke-15. Pada fase permulaan (penyesuaian), bakteri pembentuk gas bio baru menyesuaikan diri dengan lingkungan yang baru, sehingga sel belum membelah diri dan produksi gas cenderung rendah. Pada fase pertumbuhan yang dipercepat, jumlah bakteri mulai meningkat dan kemudian jumlahnya menurun pada fase stasioner (kematian), dimana bakteri mulai kekurangan nutrisi dan mengalami kematian sehingga produksi gas bio cenderung konstan dan mulai menurun [17].

Berdasarkan penelitian terdahulu, tanpa proses pre-treatment dibutuhkan waktu 31 hari [4]. Dalam penelitian ini proses pembentukan gas bio diamati dalam waktu 27 hari karena gas bio maksimum pada hari ke-18 dan menurun dalam waktu 27 hari tersebut. Oleh karena itu, pembuatan gas bio dengan proses pre-treatment memiliki potensi yang cukup bagus dibandingkan tanpa pre-treatment dari segi 
waktu yang singkat sehingga, biaya yang dikeluarkan lebih sedikit.

\section{Pengaruh Waktu Fermentasi terhadap Persentase Penyisihan COD}

COD menjadi salah satu perhatian penting dalam penelitian ini karena berpengaruh terhadap lingkungan saat sampel dibuang ke lingkungan. Persen penyisihan COD dapat dilihat dari Gambar 2.

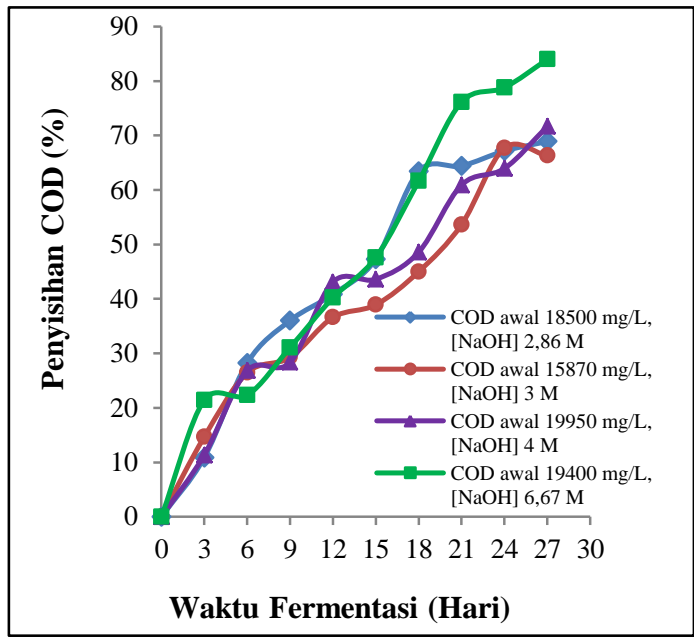

Gambar 2. Pengaruh Waktu Fermentasiterhadap Persentase Penyisihan COD

Pada Gambar 2 dapat dilihat bahwa persentase penyisihan COD pada beberapa konsentrasi $\mathrm{NaOH}$ cenderung semakin meningkat. Pada penelitian ini persentase penyisihan COD maksimum terjadi pada konsentrasi $\mathrm{NaOH}$ 6,67 M dan COD awal 19950 $\mathrm{mg} / \mathrm{L}$ hari ke-27, dengan nilai COD sebesar 2850 dan persen penyisihan COD sebesar 83,96\%. Dan penyisihan COD minimum terjadi pada konsentrasi $\mathrm{NaOH} 3 \mathrm{M}$ dan $\mathrm{COD}$ awal 15870 $\mathrm{mg} / \mathrm{L}$ hari ke-27, dengan nilai COD sebesar 4965 dan persen penyisihan COD sebesar $66,29 \%$. Dapat dilihat bahwa nilai molaritas $\mathrm{NaOH}$ yang tinggi akan mempengaruhi persentase penyisihan COD yang semakin meningkat.

Nilai COD yang sangat besar menunjukkan bahwa dalam rentang waktu tersebut banyak bahan organik dan yang dirombak oleh bakteri. Jadi semakin besar nilai kandungan COD maka kandungan zat organik dalam limbah semakin tinggi atau semakin besar jumlah penyisihan COD [11].

Penyisihan COD yang rendah disebabkan beberapa hal, yaitu bahan organik pada tahap asidifikasi dirombak menjadi asam yang selanjutnya dirombak menjadi metana pada tahap metanogenesis. Semakin besar bahan organik yang dirombak menjadi asam (VFA) dan melebihi kemampuan bakteri metanogen akan mengakibatkan proses metanogenesis terhambat dan penyisihan COD kurang maksimal [14].

Hasil penelitian menunjukkan pada beberapa komposisi sampel persentase penyisihan COD terus meningkat setelah hari ke-15 dimana produksi gas bio maksimum. Dapat dikatakan pada saat produksi gas bio optimum telah dicapai, bakteri tetap mampu mendegradasi senyawa organik meskipun volume gas bio menurun. Oleh karena itu hasil penelitian yang diperoleh belum sesuai dengan teori yang ada.

Menurut SK KEMEN LH No.1815/2014 tentang baku mutu air limbah bahwa limbah belum layak dilepaskan ke perairan lepas, apabila nilai CODnya lebih besar dari pada $100 \mathrm{mg} / \mathrm{L}$. Pada penelitian ini, nilai COD terendah dihasilkan pada konsentrasi $\mathrm{NaOH}$ 6,67M dimana jumlah COD sebesar 2850 $\mathrm{mg} /$ Ldengan persentase penyisihan COD sebesar $83,96 \%$ pada hari ke-27.

\section{Pengaruh Waktu Fermentasi terhadap Persentase Penyisihan TSS}

Pengaruh waktu fermentasi terhadap persentase penyisihan TSS pada beberapa rasio limbah eceng gondok:air. TSS merupakan partikel yang tersuspensi didalam air limbah, dapat dilihat pada Gambar 3.

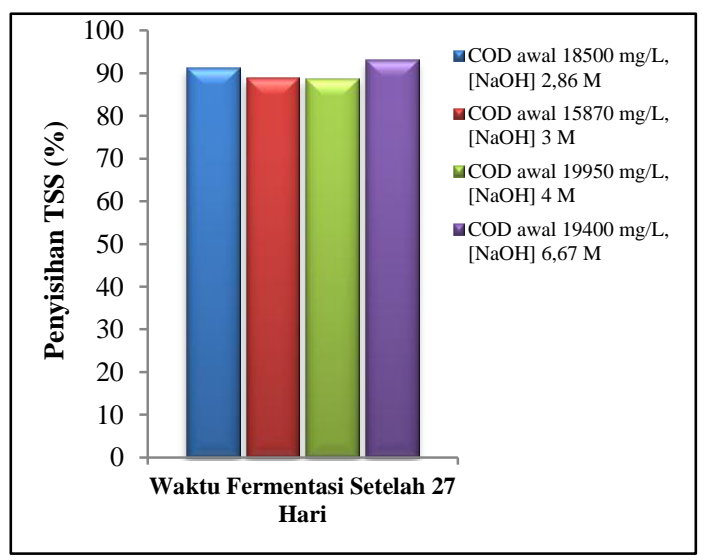

Gambar 3. Pengaruh Waktu Fermentasi terhadap Persentase Penyisihan TSS

Pada Gambar 3 dapat dilihat bahwa semakin lama waktu fermentasi maka persen penyisihan TSS akan semakin besar dan cenderung berfluktuasi denganjumlah limbah padat yang semakin besar pula.

Persentase penyisihan TSS maksimum pada penelitian ini diperolehpada konsentrasi $\mathrm{NaOH}$ 6,67 M, dapat dilihat bahwa persen penyisihan 
TSS terbesar terjadi pada hari ke-27 yaitu 93,23\%. Untuk persentase penyisihan minimum diperoleh pada konsentrasi $\mathrm{NaOH} 4 \mathrm{M}$ persen penyisihan TSS juga terjadi pada hari ke-18 yaitu sebesar $81,48 \%$.

Menurut SK KEMEN LH No.1815/2014 limbah belum layak dilepaskan ke perairan lepas, apabila nilai TSS nya lebih besar dari $200 \mathrm{mg} / \mathrm{L}$. Pada penelitian ini, jumlah TSS yang paling maksimum yaitu pada konsentrasi $\mathrm{NaOH}$ 6,67 M dengan jumlah gas bio tertinggi dimana jumlah TSS sebesar $193 \mathrm{mg} / \mathrm{L}$ dengan persentasi penyisihan TSS sebesar 93,23\% pada hari ke-27, sehingga nilai TSS tersebut memenuhi syarat kelayakan limbah untuk dilepaskan ke perairan lepas atau ke lingkungan sekitar. Berdasarkan penelitian terdahulu, nilai TSS akhir pada eceng gondok tanpa pre-treatment adalah sebesar 1,47 $\mathrm{g} / \mathrm{L}$ atau $1470 \mathrm{mg} / \mathrm{L}$ [21]. Hal ini berarti proses pre-treatment alkali dan asam mengakibatkan nilai TSS lebih rendah daripada tanpa proses pretreatment.

\section{Pengaruh Waktu Fermentasi terhadap Derajat Keasaman (pH) Pada Beberapa Komposisi Sampel}

Adapun grafik di bawah ini menunjukkan hasil penelitian pengaruh waktufermentasi terhadap derajat keasamaan $(\mathrm{pH})$ dari berbagai variasi rasio berat limbah padat .

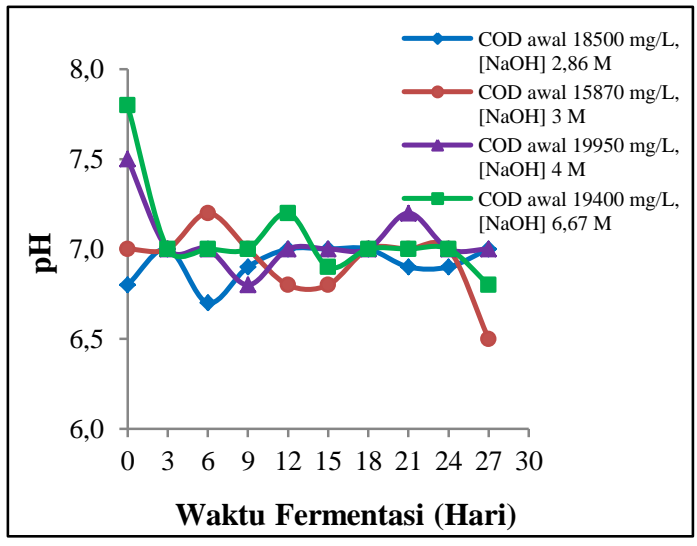

Gambar 4 Grafik Hubungan Waktu Fermentasi Terhadap Derajat Keasaman (pH)

Dari Gambar 4 dapat dilihat bahwa $\mathrm{pH}$ pada beberapa perbandingan komposisi sampel mengalami fluktuasi. Pada konsentrasi $\mathrm{NaOH}$ 6,67 M pH awal fermentasi bernilai 7,8 hal ini terjadi karena tingginya konsentrasi $\mathrm{NaOH}$ yang digunakan, namun $\mathrm{pH}$ kembali normal pada hari ke-3 karena adanya penambahan larutan buffer dan mengalami fluktuasi pada rentang $\mathrm{pH}$ 6,87,8. Adanya penambahan buffer natrium karbonat sangat berperan penting dalam menjaga
$\mathrm{pH}$ larutan selama proses fermentasi. Pada konsentrasi $\mathrm{NaOH} 2,86 \mathrm{M}$, pH awal fermentasi bernilai 6,8 dan mengalami fluktuasi hingga hari ke-27, rentang $\mathrm{pH}$ yang terjadi pada proses ini adalah 6,8-7. Untuk konsentrasi $\mathrm{NaOH} 3 \mathrm{M}$, pH awal fermentasi bernilai 6,8 danmengalami penurunan hingga hari ke-27, rentang $\mathrm{pH}$ yang dialami pada proses ini adalah 6,8-7. Untuk konsentrasi $\mathrm{NaOH} 4 \mathrm{M}, \mathrm{pH}$ awal fermentasi bernilai 7 dan mengalami fluktuasi pada rentang $\mathrm{pH}$ 6,5-7,2 selama proses fermentasi. Pada penelitian ini, $\mathrm{pH}$ paling stabil terjadi pada konsentrasi $\mathrm{NaOH} 6,67 \mathrm{M}$, sedangkan pada konsentrasi yang lebih tinggi dari 6,67 M pH yang terjadi kurang stabil.

Peningkatan $\mathrm{pH}$ optimum akan memacu proses pembusukan, sehingga meningkatkan efektivitas kerja mikrobia dan dapat meningkatkan produksi gas bio. Hasil yang diperoleh menunjukkan bahwa $\mathrm{pH}$ substrat awal 7 dengan penambahan memberikan peningkatan laju produksi gas bio lebih baik dibandingkan dengan perlakuan $\mathrm{pH}$ yang lain [22]. Dari hasil penelitian ini untuk menjagapH netral ditambahkan larutan buffer natrium karbonat, dimana dapat dilihat pada konsentrasi $\mathrm{NaOH}$ 6,67 M pada hari 15 dan 18 diperoleh volume gas yang meningkat sebesar $85 \mathrm{ml}$ ke $109 \mathrm{ml}$ dari $\mathrm{pH}$ 6,9 ke $\mathrm{pH} 7$.

Kegagalan proses pencernaan anaerobik dalam digester gas bio dikarenakan tidak seimbangnya populasi bakteri metanogenik terhadap bakteri asam yang menyebabkan lingkungan menjadi sangat asam (pH kurang dari7) dan menghambat kelangsungan hidup bakteri metanogenik. Kondisi keasaman yang optimal pada pencernaan anaerobik yaitu sekitar pH 6,8 sampai 8, laju pencernaan akan menurun pada kondisi $\mathrm{pH}$ yang lebih tinggi atau rendah [20].

\section{Hasil Uji Nyala Gas Bio}

Hasil uji nyala gas bio pada penelitian ini dapat dilihat pada Tabel 2 di bawah ini.

Tabel 2. Hasil uji nyala gas bio Beberapa Perbandingan Sampel

\begin{tabular}{|c|c|c|}
\hline $\begin{array}{c}\text { Eceng } \\
\text { gondok } \\
\text { :air }\end{array}$ & $\begin{array}{c}\text { Konsentrasi } \\
\text { NaOH (M) }\end{array}$ & Hasil Uji Nyala \\
\hline $70: 30$ & 6,67 & Api berwarna biru \\
\hline $50: 50$ & 2,86 & Api berwarna biru \\
\hline $30: 70$ & 3,00 & Api berwarna biru \\
\hline $100: 0$ & 4,00 & Api berwarna biru \\
\hline
\end{tabular}

Uji pembakaran yang menunjukkan bahwa gas berwarna biru ini menandakan api cukup bagus untukdimanfaatkan sebagai sumber 
energi. Hasil uji pembakaranmenunjukkan bahwa semua gas hasil fermentasi pada setiap variabel dapat dibakar danmengandung metana $\left(\mathrm{CH}_{4}\right)$ [22], dimana metana $\left(\mathrm{CH}_{4}\right)$ adalah komponen penting dan utama dari gas bio karena memiliki kadar kalor yangcukup tinggi dan jika gas yang dihasilkan dari proses fermentasi anaerob inidapat terbakar, hal ini menunjukkan bahwa sedikitnya mengandung $45 \%$ metana. Berdasarkan penelitian yang telah dilakukan nyala api membuktikan berwarna biru. Apabila gas yang dihasilkan adalah $\mathrm{CO}_{2}$, api yang dinyalakan akan mati [3].

\section{Kesimpulan}

Semakin besar jumlah limbah padat maka semakin besar jumlah volume gas bio danpenyisihan TSS. Volume gas bio dan penyisihan TSS maksimum diperoleh pada rasio eceng gondok: air 70:30 (v/v) dengan konsentrasi $\mathrm{NaOH}$ 6,67 M pada hari ke-27 dengan volume total gas bio sebesar $506 \mathrm{~mL}$ dan penyisihan TSS $93,23 \%$. Hasil analisa uji nyala gas bio pada setiap variasi menunjukkan nyala api biru yang menandakan gas metana lebih dari $45 \%$. Proses pre-treatment natrium hidroksida dan asam sulfat pada bahan baku mengakibatkan waktu fermentasi lebih cepat (27 hari). Untuk volume gasbio dan penyisihan TSS maksimum tanpa pre-treatment diperoleh pada rasio 75:25 pada hari 31 dengan volume total gas bio sebesar 319 $\mathrm{mL}$ dan penyisihan TSS 93,79\%.

\section{Daftar Pustaka}

[1] A. A. Fikri dan S. R. Muria, Pengaruh Perbandingan Eceng Gondok dengan Air Terhadap Penyisihan COD dan Padatan pada Produksi Biohidrogen Secara Fermentasi Anaerob Batch Tahap Asidogenesis, Jurnal Jom Fteknik, Volume 2 No. 2, 2015.

[2] A. D. Broughton, Hydrolysis And Acidogenesis of Farm Dairy Effluent for Biogas Production at Ambient Temperatures, Thesis for The Degree of Master of Engineering in Environmental Engineering, Massey University, Palmerston North, New Zealand, 2009.

[3] A. F. Utomo dan N. Primastuti, Pemanfaatan Limbah Furniture Enceng Gondok (Eichhornia Crassipes) di Koen Gallery Sebagai Bahan Dasar Pembuatan Briket Bioarang, Jurnal Teknologi Kimia dan Industri, Vol.2, No.2. Hal: 220-225, 2013.

[4] A. U. Ofoefule., E. O. Uzodinma and O. D. Onukwuli, Comparative Study of The Effect of Different Pre-Treatment Methods on Biogas Yield from Water Hyacinth (Eichhornia Crassipes), International Journal of Physical Sciences Vol. 4 (8), pp. 535-539, 2009.

[5] C. W. Yuwono dan T. Soehartanto, Perancangan pada Sistem Pengaduk Bioreaktor Batch Untuk Meningkatkan Produksi Gas Bio, Jurnal Teknik Pomits Vol. 2, No. 1, 2013.

[6] D. Clinton, Pengaruh Waktu Fermentasi dan Komposisi Limbah Kulit Buah Aren (Arenga Pinnata) dengan Starter Kotoran Sapi Terhadap Gas Bio yang Dihasilkan, Jurnal Teknik Kimia USU, Vol. 4, No. 3, 2015.

[7] D. Dieter and A. S. hauster, Biogas from Waste and Renewable Resources, An Introduction (Singapore: WILEY-VCH Verlag GmbH \& Co. KGaA,Weinheim), 2008.

[8] D. Krishna and A. S. Kalamdhad, PreTreatment and Anaerobic Digestion of Food Waste for High Rate Methane Production - A Review, Journal of Environmental Chemical Engineering, Vol 2, 2014.

[9] D. Padmono, Kemampuan Alkalinitas Kapasitas Penyangga (Buffer Capacity) dalam Sistem Anaerobik Fixed Bed, Jurnal Teknik Lingkungan, 8 (2): 119-127, 2007.

[10] E. Sari., S. Syamsiah., H. Sulistyo and M. Hidayat, Effect Of $\mathrm{Mn}^{2+}$ Addition on Delignification of Water Hyacinth Using Phanerochaete Chrysosporium, Modern Applied Science, Vol. 9, No. 2, 2015.

[11] E. Suriadi, Pengaruh Konsentrasi COD Terhadap Efektivitas Pengolahan Air Limbah Secara UASB, Bulletin Penelitian, Vol. XIX, No. 1, 1997.

[12] F. Agustina, Aplikasi Parameter Produk Gas Bio dari Limbah Cair Industri Tapioka dalam Bioreaktor Anaerobik 2 Tahap, Magister Teknik Kimia, Universitas Diponegoro, Semarang, 2012.

[13] F. Amriani, Praperlakuan Fisik dan Biologi Terhadap Biomassa Eceng Gondok Untuk Produksi Enzim Selulase oleh Aspergillus Niger dan Trichoderma Reesei, Skripsi, Fakultas Teknik, Universitas Sumatera Utara, Medan, 2013.

[14] Farida, Pemanfaatan Serat Enceng Gondok dan Kitosan Sebagai Bahan Baku Untuk Pembuatan Poly Lactic Acid Sebagai Kemasan Ramah Lingkungan, Skripsi, Fakultas Matematika Dan Ilmu Pengetahuan Alam, Universitas Sumatera Utara, Medan, 2012. 
[15] G. A. GmbH, Biogas Purificion and Assessment Of The Nural Gas Grid, Austria, Leitbnitz, 2008.

[16] J. Abdillah dan G. R. Mahadin, Hidrolisa Basa dalam Pre-Treatment Produksi Gas Bio dengan Bahan Baku Eceng Gondok, Skripsi, Jurusan Teknik Kimia, Institut Teknologi Semarang, 2011.

[17] L. N. Hakim., Nurwantoro dan A. Purnomoadi, Gas Production and BioDigester Gas Production Rate with Addition of Rice Husks Into Cattle Facces as Raw Material, Animal Agriculture Journal, Vol. 1. No. 2, p 342 - 351, 2012.

[18] O. Almoustaph., S. Kenfack and J. M. Rasolodimby, Biogas Production Using Water Hyacinths to Meet Collective Energy Needs in A Sahelian Country, Published by Copernicus Publications on behalf of the Institut Veolia Environnement,Field Actions Sci. Rep., 2, 27-32, 2009.

[19] S. Wahyuni, Gas Bio Energi Terbarukan Ramah Lingkungan dan Berkelanjuta, Kongres Ilmu Pengetahuan Nasional (KIPNAS) ke 10, Jakarta, 2011.

[20] T. Haryati, Gas Bio : Limbah Peternakan yang Menjadi Sumber Energi Alternatif, Balai Penelitian Terna/ PO Box 221, Bogor, 2006.

[21] W. Panggih, Produksi Gas Bio dari Eceng Gondok, Seminar Tesis Program Magister, Teknik Lingkungan ITS, 2011.

[22] Wagiman, Identification of Potential Biogas Production from Tofu Wastewater With Upflow Anaerobic Sludge Blanket Reactor (UASB), Bioteknologi4 (2): 41-45, 2007.

[23] Y. D. Yenni, Uji Pembentukan Substrat dari Substrat Sampah Sayur dan Buah dengan Ko-Substrat Limbah Isi Rumen Sapi, Jurnal Teknik Lingkungan UNAND 9 (1): 26-36, 2012.

[24] Y. S. Dewi, Efektivitas Jumlah Rumpun Tanaman Eceng Gondok (Eichhornia Crassipes) dalam Pengendalian Limbah Cair Domestik, Jurnal Riset Industri Vol. V, No.2, Hal 131-142, 2011. 